\title{
Landslide susceptibility mapping along Tulsipur-Kapurkot road section and its surrounding region using bivariate statistical model
}

\author{
Khagendra Poudel ${ }^{1}$ and *Amar Deep Regmi ${ }^{2,3}$ \\ ${ }^{1}$ Central Department of Geology, Tribhuvan University, Kathmandu, Nepal \\ ${ }^{2}$ Nepal Academy of Science and Technology, Lalitpur, Nepal \\ ${ }^{3}$ Key Laboratory of Mountain Hazards and Surface Process, Institute of Mountain Hazards and Environment, \\ Chinese Academy of Sciences, Chengdu, Sichuan 610044, China \\ (*E-mail: amardeep_regmi@yahoo.com)
}

\begin{abstract}
The Tulsipur-Kapurkot road is the main highway connecting the northern part of Rapti zone to the rest of Nepal. It suffers from numerous mass movements obstructing the traffic every monsoon. This paper describes the development of landslide susceptibility map of the road section and its surrounding regions based on bivariate (frequency ratio) statistical model. Geologically, the road section passes through the rocks of Lesser Himalaya, Siwaliks and Quaternary deposits. Several large and small scale thrusts present within the area making it unstable. For the susceptibility evaluation of the region, first a landslide inventory map consisting more than 187 landslides was prepared. These landslide locations were then randomly partitioned into a ratio of 80/20 for training and validating the models. Second, nine landslide causative factors were prepared. They include slope, aspect, elevation, curvature, geology, land use, distance from fault, distance from river and distance from major road sections. Finally, a landslide susceptibility map of the region was obtained and it was validated using area under curve (AUC). From the analysis, the success rate of the model is found to be $85.18 \%$ and predictive accuracy is $78.76 \%$. The resultant susceptibility map shows that the highway in between Ranagaun to Khamari and Ramri to Kapurkot falls within very high to high susceptible zone. Besides, it is observed that the Kapurkot Bazar is also under high landslide susceptible zone. Furthermore, the northern part of the watershed lies in high landslide susceptible zone. The result of this study is useful for land use planning and decision making in landslide management activities.
\end{abstract}

Keywords: Landslide inventory, Landslide susceptibility map, Frequency ratio, bivariate statistical model, Rapti zone

Paper Received: 08 May 2015

Paper Accepted: 10 November 2015

\section{INTRODUCTION}

The Himalaya is geologically very young and tectonically most unstable mountain landscapes of the world (Searle et al. 1987). These landscapes are vulnerable to various natural hazards, including landslides, debris flows and soil erosion primarily triggered by extensive rainfall of monsoon (Dahal et al. 2006). Catastrophic events such as landslide, flooding are frequently interconnected by casual links, e.g. sometime landslide dams the river and sudden break of dam cause flooding in downstream (Carrara 1999). Weak geological characteristics along with improper land use practices for cultivation and road construction have made Tulsipur-Kapurkot road section and its surrounding highly susceptible to landslide and related hazards. Each year, several people are killed and huge amount of private and public property is damaged due to these events. According to the data from the Ministry of Homes, Government of Nepal more than 100 peoples are killed every year.

Landslide susceptibility mapping (LSM) and assessment can provide useful information for disaster loss reduction, and assist in the development of guidelines for sustainable land use planning. In the LSM, the basic principle is to identify the factors that are most influential in forming the landslides in the region as well as to estimate the relative contribution of each factor causing slope failures, establish a relation between the factors and landslides, and to predict the landslide hazard in the future based on such a relationship (Chen and Wang 2007). There are several approaches for developing landslide susceptibility and they can be categorized into three distinct groups: (i) deterministic (or engineering or geotechnical), (ii) the heuristic (or index) and (iii) the statistical methods (Varnes 1984, Regmi et al. 2014). In the statistical approach, multivariate and bivariate statistical techniques are most widely used throughout the world (Dai and Lee 2002, Donati and Turrini 2002). Bivariate statistical analyses compares landslide inventory map with maps of landslide influencing parameters in order to rank the corresponding classes according to their role in landslide formation (Regmi et al. 2013).

The Tulsipur-Kapurkot road section connects Rolpa and Salyan districts with rest of the country and there is no alternate option for this road section. Thus, to maintain the smooth operation of the traffic as well as to minimise the losses of life and property, landslide susceptibility assessment is essential for this road section and its surrounding regions. 
In this respect, we have used frequency ratio (FR) model for developing the landslide susceptibility map of this road section and its surrounding area. This method is easy to apply and it gives very good result.

\section{STUDY AREA}

The Tulsipur-Kapurkot road section runs for a distance of $18 \mathrm{~km}$ in the southern flat land, followed by hills and high mountains in the western Nepal Himalaya. It lies within the latitude $28^{\circ} 06^{\prime} \mathrm{N}$ to $28^{\circ} 15^{\prime} \mathrm{N}$ and the longitude $82^{\circ} 16^{\prime} \mathrm{E}$ to $82^{\circ} 21^{\prime} \mathrm{E}$ of the topographic map Tulsipur (Sheet No. 2882-14 A). The study area covers an area of about $74.03 \mathrm{~km}^{2}$. The minimum and maximum altitudes of the area are $600 \mathrm{~m}$ at Tulsipur Bazar and 2,050 $\mathrm{m}$ in between Makkhankuti and Phallaban gaun (Fig. 1). The main settlements in the study area are Kapurkot, Balle, Kalle, Ramri, Ambas, Khamari, Lahurechaur, Ranagaun, Dandakhuti, Raksachaur, Budune, Doghare and Tulsipur (Fig. 1). The Patu Khola along with its major tributaries (the Gahate Khola, Balle Khola, and Kapurkot Khola) drains the entire study area. Tropical to subtropical climatic condition prevails in the study area. The main characteristics of the climate in the study area is the monsoon rainfall, which occurs between June and September and delivers an average of $85 \%$ of the total rainfall of the year (Nayava 1980).

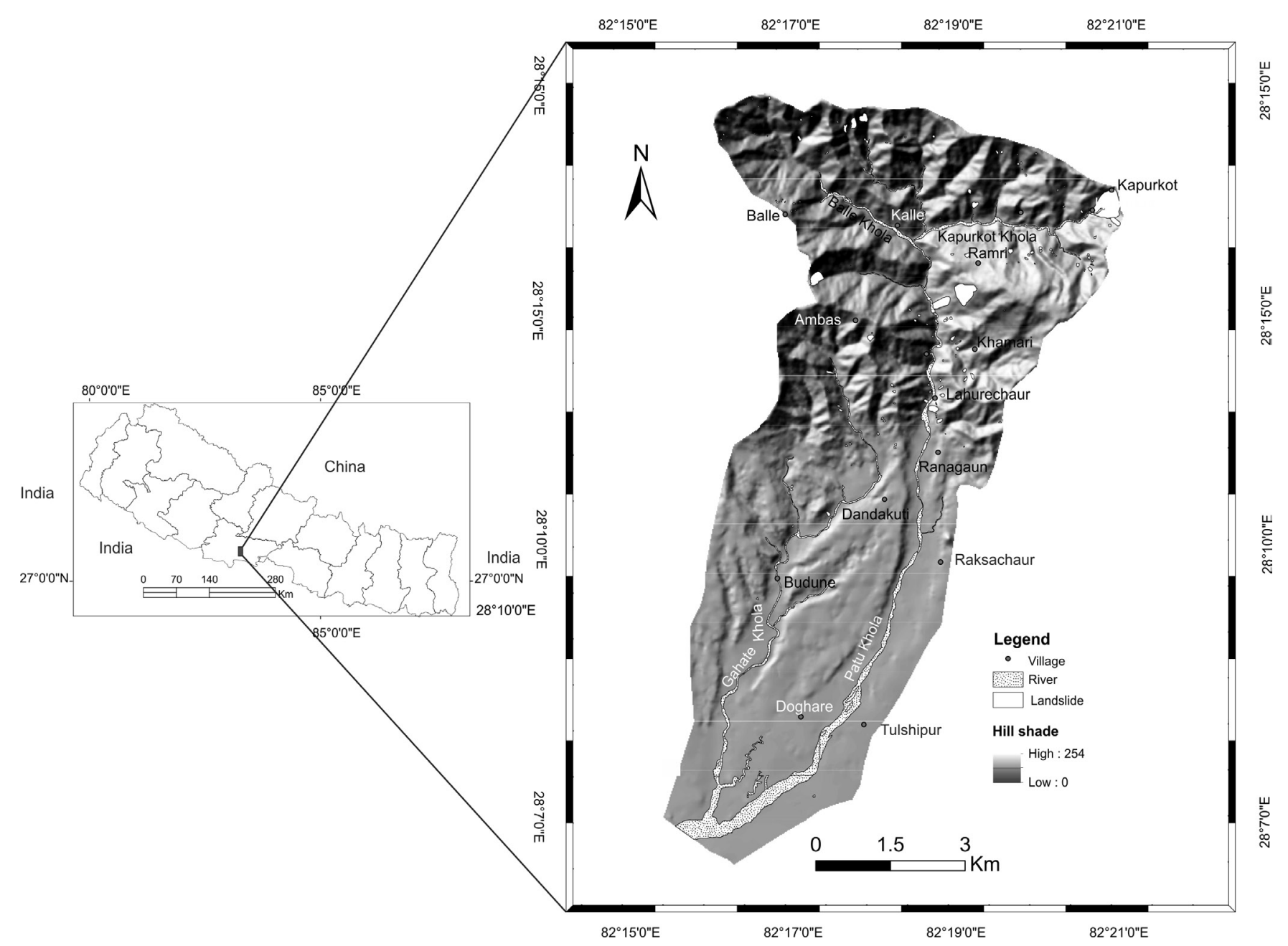

Fig. 1: Location map of the study area showing the distribution of landslides.

\section{GEOLOGICAL SETTING}

The Tulsipur Kapurkot section of the highway and its surrounding region passes through the Quaternary deposits, Siwaliks and Precambrian Lesser Himalayan rocks (Fig. 2).
The Recent Quaternary deposit comprises silt, sand to cobble, pebble and boulder deposits whereas older Quaternary deposit contains loose, sub angular to rounded pebbles of sandstone, dolomite and phyllite (Laudari 2001). 


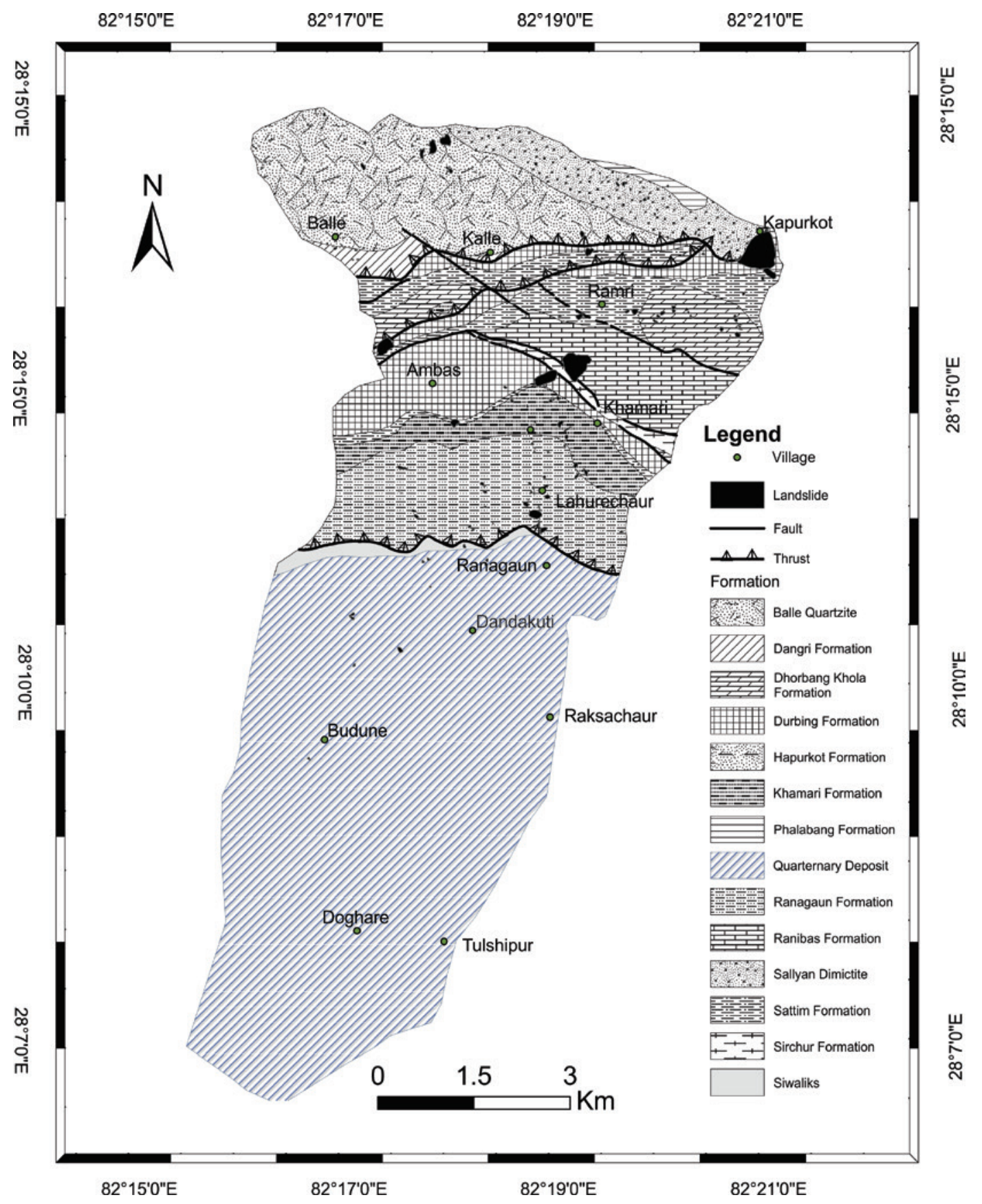

Fig. 2: Geological map of the study area.

Most parts of the Siwaliks are covered by Quaternary deposit, except along the Patu Khola (Fig. 2). The exposed part of the Siwaliks comprises interbedding of fine grained grey sandstone and red purple, yellow brown mudstone and can be correlated with the Bankas Formation of Siwaliks in Mid-western Nepal (Dhital et al. 1995).

Along the north foothills of Dang valley the Botechaur Thrust and Main Boundary active fault, alias the Main Boundary Thrust (Dhital 2015). The sedimentary rocks bounded by the Botechaur Thrust and Kapurkot Thrust belong to Daban Supergroup further subdivided categorised into Tosh and Gwar Group. The low grade metasedimentary rocks resting over the Kapurkot Thrust constitute the Sharda Group (Dhital 2015). In Dang and Salyan districts of west Nepal the Kapurkot Thrust and the Botechaur Thrust played the role of roof thrust and floor thrust respectively forming large duplex (Dhital and Kizaki 1987a).The Sharda Group consists of Dangri, Balle Quartzite, Salyan Diamictite and Phalbang formations from bottom to 
top respectively (Dhital and Kizaki 1987b). The Proterozoic Gwar Group and Tosh Group consist of Ranagaon, Khamri, Hapurkot, Dhorban Khola, Sirchaur, Ranibas, Sattim, and Dubring formations respectively (Dhital and Kizaki 1987b). The Gwar Group is separated from the overlying Tosh Group by disconformity with erosional surfaces whereas its lower part is delimited by the Botechaur Thrust (Dhital 2015). The main rock types are dolomite, limestone, slate, shale, claystone, quartzite, sandstone, mudstone, and some coal seams.

\section{METHODOLOGY}

\section{Landslide inventory mapping}

Identifying and evaluating landslide prone areas and constructing a landslide inventory map usually involves techniques such as field survey, air photo interpretation, and literature search for historical landslide records (Wieczorek 1984, Nandi and Shakoor 2009). This step is considered as the
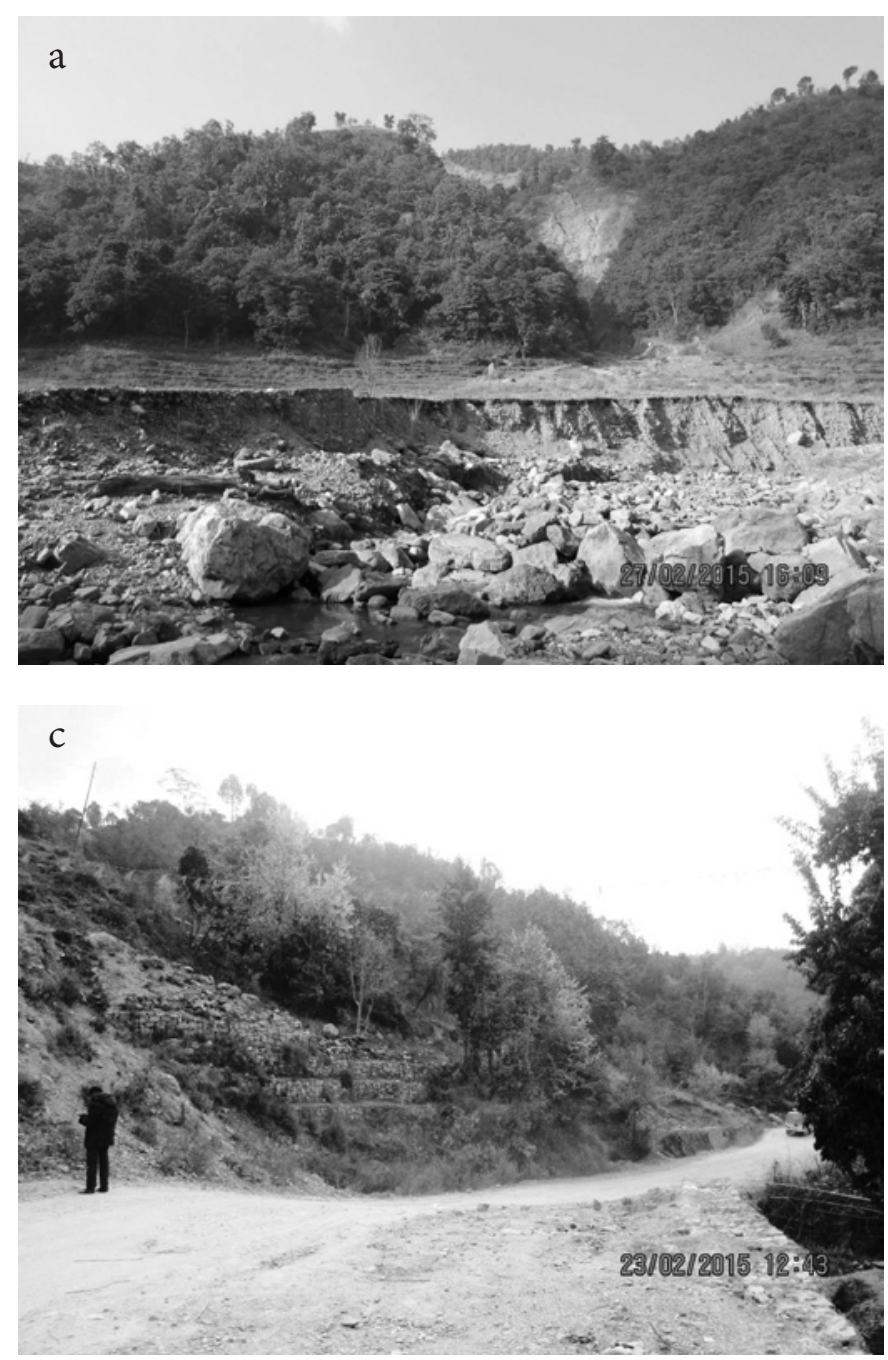

most important part in the landslide susceptibility mapping. It gives insight into the location, types, failure mechanism, trigger as well as the frequency of occurrence, volumes and the damage associated with the landslide (van Westen et al. 2008). Thus to develop the LSM of the Tulsipur-Kapurkot road section and its surrounding region, we developed a landslide distribution map based on the Google Earth image interpretation and detailed field survey using GPS (Fig. 1).

Detailed field survey of the study area revealed that the extreme rainstorm during monsoon makes the area suffer from both flash flood and landslides. In one place, it is seen that the river was dammed by a landslide leading to flooding in downstream (Fig. 3a). The whole Kapurkot Bazaar is under threat where transverse cracks and damages to houses can be seen (Fig. 3b). Road subsidence is another problem caused each year by the landslide near Kapurkot (Fig. 3c). Similarly, very large complex landslide to the west of Kapurkot Bazar has made the whole settlement in very high risk (Fig. 3d).
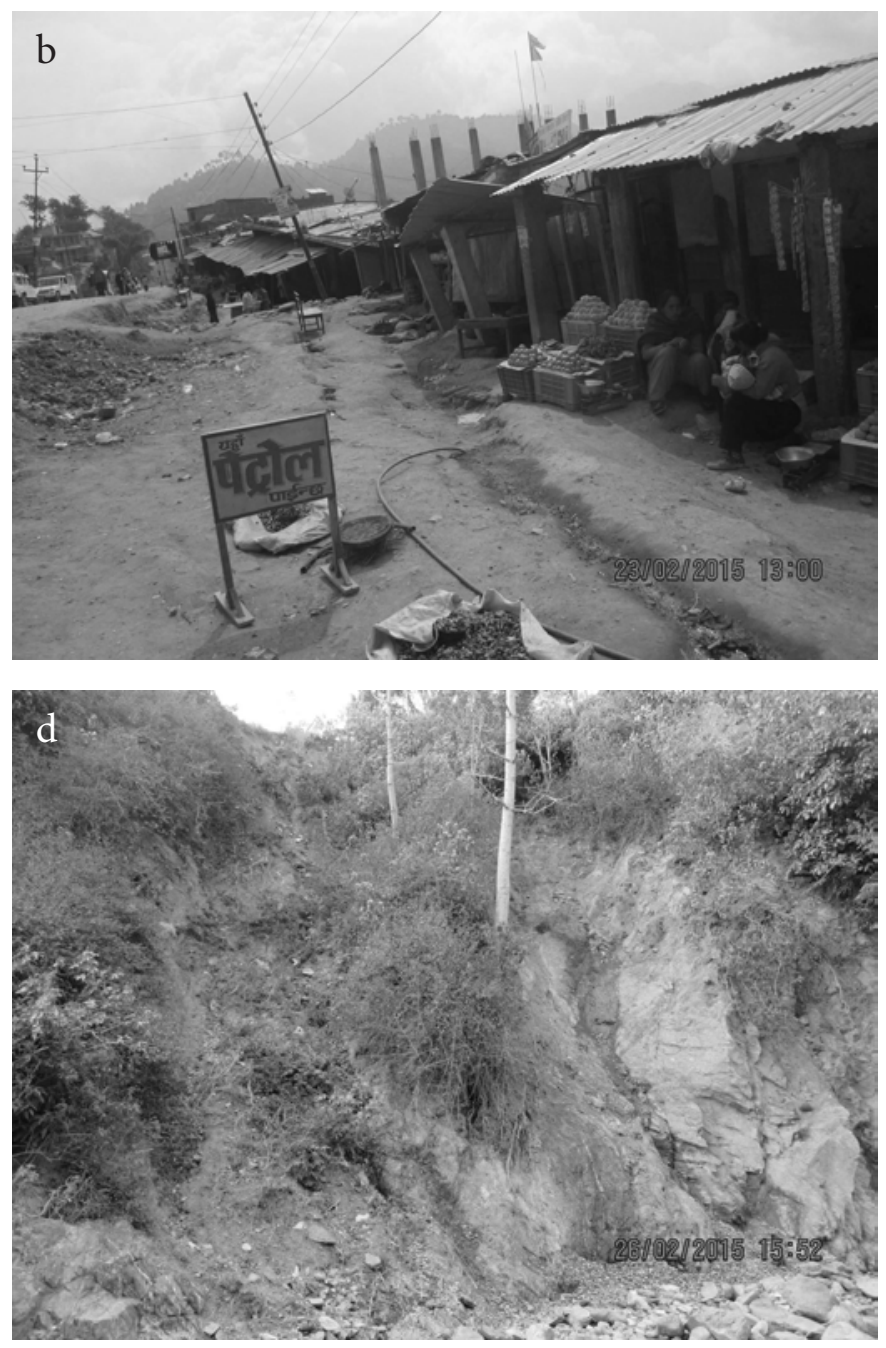

Fig. 3: Different types of landslides and associated features the study area. (a) Thick debris deposit by a landslide near Balle, that dammed the river for some time; (b) Transverse cracks observed in Kapurkot Bazar; (c) Road subsidence due to a landside near Kapurkot; (d) Landslide observed near MBT at Gahate Khola. 


\section{Data preparation for landslide susceptibility mapping}

The second step is the preparation of landslide susceptibility map showing the probability that a phenomenon would occur in an area on the basis of the local terrain conditions (Soeters and van Westen 1996). To construct such maps, first we have to know the factors that are most influential in forming the instabilities in the region. In this respect, knowledge of the local geologic conditions affecting landslides is most important (Guzzetti et al. 1999). Slope angle, aspect, elevation, curvature, geology, land use, distance from fault, distance from river and distance from major road sections are considered as the most important causative factors for the instabilities in the region. The slope angle, aspect, elevation, and curvature maps were derived from the digital elevation model (DEM) constructed from the topographic data with pixel size of $20 \mathrm{~m}$ x $20 \mathrm{~m}$. The geological map was used to derive the lithological and fault distance maps. Similarly, distance from river and distance from major road sections were developed from the river and road maps provided by the Department of Survey, Government of Nepal and Beside, the land use map was used for the susceptibility mapping of the region. The detail description of the data layers used in the present study is given below.

\section{Slope gradient}

Slopes affect soil water content (surface and subsurface), soil formation, erosion potential hence it has been widely shown that landslides tend to occur more frequently on steeper slopes. Places where the slope is very gentle or near vertical are considered to be safer in terms of failure initiation (McDermid and Franklin 1995, Cooke and Doornkamp 1990). The slope map was produced in ArcGIS 10 using the DEM with $20 \mathrm{~m} \mathrm{x}$ $20 \mathrm{~m}$ grid size and is divided into 8 categories (Fig. 4a).

\section{Slope aspect}

Aspect is a compass direction class and is expressed in degree in clockwise direction. The slope aspect map was also produced from the DEM and is divided into 8 classes as north, north east, east, south east, south, south west, west and North West (Fig. 4b).

\section{Plan curvature}

Plan curvature is also considered as one of the most important factor responsible for instabilities. Hence, we have used it as one of the causative factor. The curvature map was derived from the DEM with $20 \mathrm{~m}$ x $20 \mathrm{~m}$ grid size in ArcGIS 10. The map is reclassified into three classes: concave, flat and convex (Fig. 4c).

\section{Elevation}

Although relationship between landslide activity and elevation is still unclear, elevation influences a large number of biophysical parameters and anthropogenic activities. In turn, these conditions are likely to affect slope stability and generate slope failure (Vivas 1992). The elevation map was produced using the DEM with $20 \mathrm{~m}$ x $20 \mathrm{~m}$ grid size which is reclassified into 8 classes with $150 \mathrm{~m}$ interval (Fig. 4d).

\section{Lithology}

Lithology plays an important role in the instabilities of a region, as different lithological units have different physical/chemical properties making them variable in failure mechanisms. Hard rocks are less susceptible to landslides, while soft rocks are more prone to sliding. Similarly, interlayering of soft and hard rock make the situation more complex. The lithological map (Fig. 2) is derived from the geological map of the region by Dhital and Kazaki (1978a).

\section{Distance from faults}

The spatial distribution of landslides in the study area shows a good correlation with the Kapurkot Thrust, MBT and other normal faults. As the rocks around the thrusts and faults are more disturbed, the strength is highly reduced here making the region around these tectonic features more susceptible for failure. A buffer map relating the fault distance with a $50 \mathrm{~m}$ buffer interval is shown in Fig. 4e.

\section{Distance from rivers}

Runoff plays an important role as a triggering factor for landslides (Regmi et al. 2013). The distance from rivers is represented by the proximity of the rivers in the area. The river map obtained from the Department of Survey, Government of Nepal was used in Arc GIS 10 to get the proximity to rivers (Fig. 4f).

\section{Distance from major roads}

During the process of road construction, natural condition or stability of the slope is disturbed which makes landslides very common along road cuts. This is mainly due to the fact that the road cut exposes the joints and fractures, as well as it alters the natural condition of the slope making it unstable (Regmi et al. 2013). Also, a given road segment may act as a barrier, a net source, a net sink, or a corridor for water flow, which usually serves as a source of landslides (Pradhan 2010). The Tulsipur-Kapurkot Highway is buffered with a buffer distance of $50 \mathrm{~m}$ in Arc GIS 10 to generate the distance in the highway map (Fig. 4g).

\section{Land use}

Land use plays a significant role in the stability of the slope as parameters, like cohesion, internal friction angle, weight of the soil and pore-water pressure, all tend to be substantially modified by the presence of vegetation. (Gomez and Kavzoglu 2003). The land use map (Fig. 4h) prepared by the Survey Department, Government of Nepal consists of nine classes, namely barren land, cultivation, forest, orchard, grassland, bushes, sand cover, river and pond/lake. Forest (53 $\%$ ) covers the largest area followed by cultivation land (33\%).

\section{Modeling approach}

The last step in LSM usually involves an assessment of the areas with potential to landsliding in the future (Cascini 2008). The unique combination of several spatial input datasets creates a susceptibility map representing different susceptible classes as; very low, low, moderate, high, and very high (Soeters 
Poudel et al.
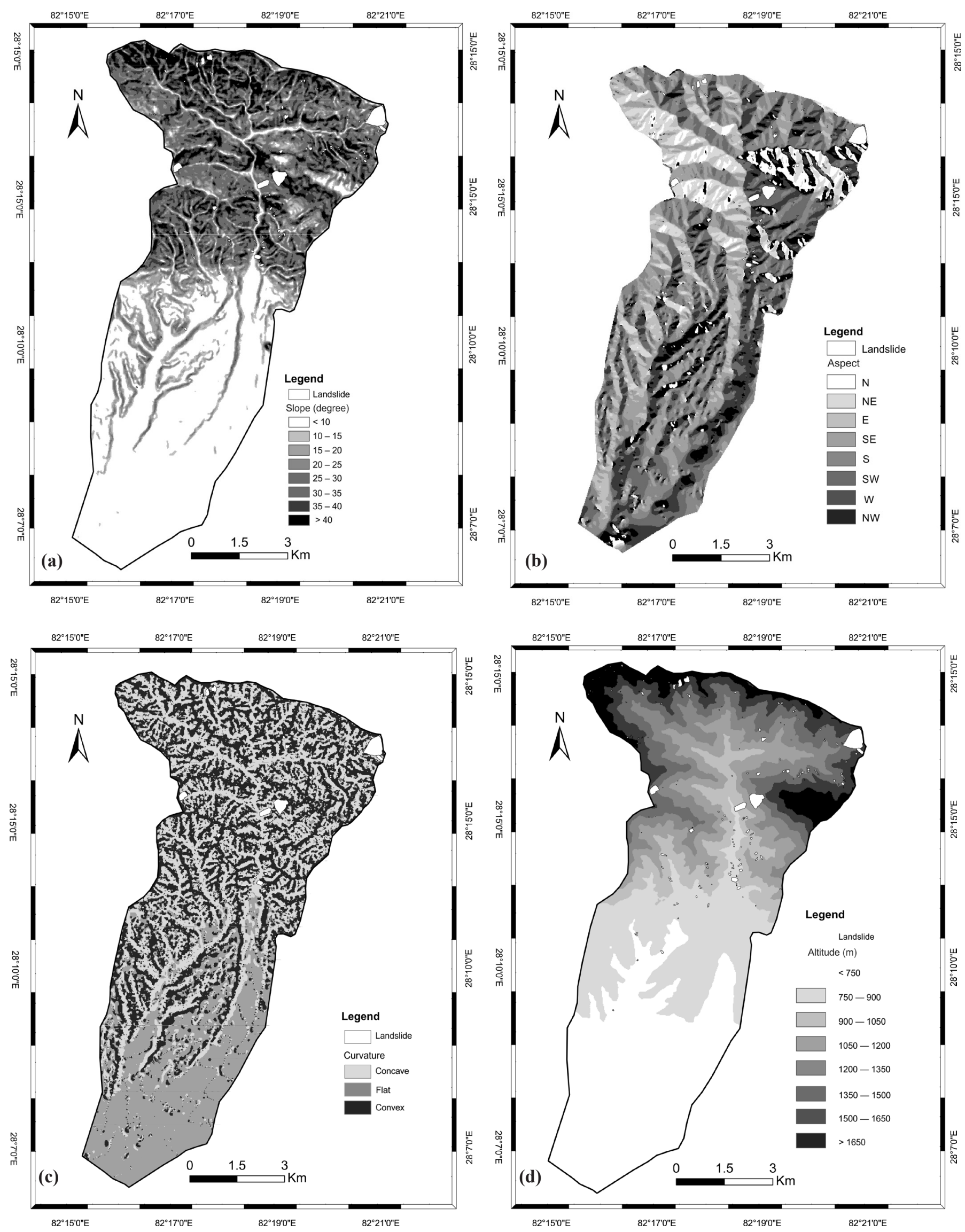

Fig. 4: Thematic maps used in this study. (a) Slope gradient map (in degree); (b) Slope aspect map; (c) Plan curvature map; (d) Elevation map (in meter). 


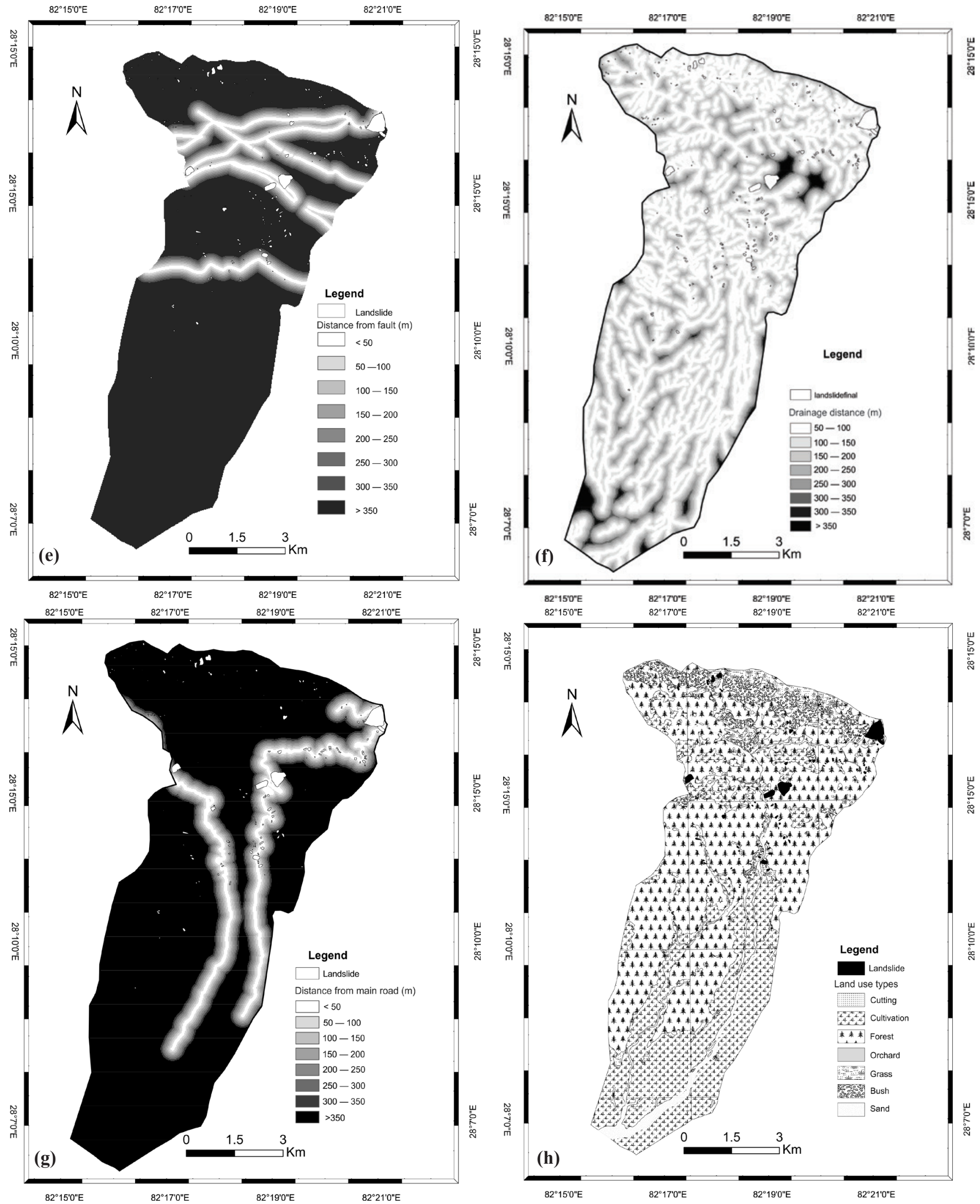

Fig. 4: (e) Distance from faults map (in meter); (f) Distance from rivers map; (g) Distance from major roads map; and (h) Land use. 
and van Westen 1996, Brabb et al. 1998, Guzzetti et al. 1999, Lee and Min 2001). In his study, we have used FR (Frequency Ratio) model for developing the susceptibility map of the area. The FR is defined as the ratio of the probabilities of a landslide occurrence to a nonoccurrence for a given attribute (BonhamCarter 1994, Pradhan and Lee 2009). It can be expressed by

Where,

$$
L S I=\sum F R
$$

LSI is the landslide susceptibility index and FR is the frequency ratio.

FR is expressed as:

$$
F R=\frac{\frac{N p i x\left(S X_{i}\right)}{\sum_{i=1}^{m} S X_{i}}}{\frac{N p i x\left(X_{j}\right)}{\sum_{j=1}^{n} N p i x\left(X_{j}\right)}}
$$

Where,

$N p i x\left(X_{i}\right)$ is the number of pixels with landslides within class i of parameter variable $\mathrm{X}, \quad \operatorname{Npix}\left(X_{j}\right)$ is the number of pixels within parameter variable $\mathrm{Xj}, \mathrm{m}$ is the number of classes in the parameter variable $\mathrm{Xi}$, and $\mathrm{n}$ is the number of parameters in the study area (Regmi et al. 2014).

\begin{tabular}{|c|c|c|c|c|c|c|}
\hline Factors & Class & No. of pix & \% of class & No. of Isd & $\%$ of Isd & Weight \\
\hline \multirow{8}{*}{ Slope gradient } & $0^{\circ}-10^{\circ}$ & 73332 & 39.62 & 3 & 1.92 & 0.05 \\
\hline & $10^{\circ}-15^{\circ}$ & 11459 & 6.19 & 4 & 2.56 & 0.41 \\
\hline & $15^{\circ}-20^{\circ}$ & 12366 & 6.68 & 9 & 5.77 & 0.86 \\
\hline & $20^{\circ}-25^{\circ}$ & 14601 & 7.89 & 18 & 11.54 & 1.46 \\
\hline & $25^{\circ}-30^{\circ}$ & 18122 & 9.79 & 21 & 13.46 & 1.37 \\
\hline & $30^{\circ}-35^{\circ}$ & 21914 & 11.84 & 31 & 19.87 & 1.68 \\
\hline & $35^{\circ}-40^{\circ}$ & 20349 & 11.00 & 37 & 23.72 & 2.16 \\
\hline & $>40^{\circ}$ & 12925 & 6.98 & 33 & 21.15 & 3.03 \\
\hline \multirow{8}{*}{ Slope aspect } & North & 10139 & 5.48 & 14 & 8.97 & 1.64 \\
\hline & North East & 14032 & 7.58 & 15 & 9.62 & 1.27 \\
\hline & East & 19108 & 10.32 & 22 & 14.10 & 1.37 \\
\hline & South East & 29264 & 15.81 & 31 & 19.87 & 1.26 \\
\hline & \begin{tabular}{|l|} 
South \\
\end{tabular} & 31531 & 17.04 & 24 & 15.38 & 0.90 \\
\hline & South West & 37122 & 20.06 & 25 & 16.03 & 0.80 \\
\hline & West & 28314 & 15.30 & 15 & 9.62 & 0.63 \\
\hline & North West & 15558 & 8.41 & 10 & 6.41 & 0.76 \\
\hline \multirow{3}{*}{ Plan curvature } & Concave & 94441 & 51.03 & 68 & 43.59 & 0.85 \\
\hline & Flat & 2485 & 1.34 & 0 & 0.00 & 0.00 \\
\hline & Convex & 88142 & 47.63 & 88 & 56.41 & 1.18 \\
\hline \multirow{8}{*}{ Elevation } & $<750 \mathrm{~m}$ & 93573 & 50.56 & 20 & 12.82 & 0.25 \\
\hline & $750 m-900 m$ & 14995 & 8.10 & 19 & 12.18 & 1.50 \\
\hline & $900 \mathrm{~m}-1050 \mathrm{~m}$ & 18511 & 10.00 & 12 & 7.69 & 0.77 \\
\hline & $1050 \mathrm{~m}-1200 \mathrm{~m}$ & 18106 & 9.78 & 17 & 10.90 & 1.11 \\
\hline & $1200 m-1350 m$ & 16729 & 9.04 & 37 & 23.72 & 2.62 \\
\hline & $1350 \mathrm{~m}-1500 \mathrm{~m}$ & 12725 & 6.88 & 32 & 20.51 & 2.98 \\
\hline & $1500 \mathrm{~m}-1650 \mathrm{~m}$ & 8078 & 4.36 & 11 & 7.05 & 1.62 \\
\hline & $>1650 \mathrm{~m}$ & 2351 & 1.27 & 8 & 5.13 & 4.04 \\
\hline \multirow{14}{*}{ Lithology } & Quaternary deposit & 89103 & 48.15 & 10 & 6.41 & 0.13 \\
\hline & Siwaliks & 1520 & 0.82 & 1 & 0.64 & 0.78 \\
\hline & Dubring Formation & 13877 & 7.50 & 20 & 12.82 & 1.71 \\
\hline & Sattim Formation & 10240 & 5.53 & 11 & 7.05 & 1.27 \\
\hline & Ranibas Formation & 7911 & 4.27 & 3 & 1.92 & 0.45 \\
\hline & Sirchur Formation & 1282 & 0.69 & 1 & 0.64 & 0.93 \\
\hline & Dhorbang Khola Formation & 6974 & 3.77 & 19 & 12.18 & 3.23 \\
\hline & Hapurkot Formation & 2 & 0.00 & 0 & 0.00 & 0.00 \\
\hline & Khamari Formation & 6271 & 3.39 & 9 & 5.77 & 1.70 \\
\hline & Ranagaun Formation & 16862 & 9.11 & 27 & 17.31 & 1.90 \\
\hline & Phalabang Formation & 750 & 0.41 & 0 & 0.00 & 0.00 \\
\hline & Sallyan Dimictite & 7388 & 3.99 & 15 & 9.62 & 2.41 \\
\hline & Balle Quartzite & 21165 & 11.44 & 32 & 20.51 & 1.79 \\
\hline & Dangri Formation & 1723 & 0.93 & 8 & 5.13 & 5.51 \\
\hline
\end{tabular}

Table 1: Spatial relationship between each factor and landslide by the FR. 
Landslide susceptibility mapping along Tulsipur-Kapurkot road section

\begin{tabular}{|c|c|c|c|c|c|c|}
\hline \multirow{8}{*}{$\begin{array}{l}\text { Distance from } \\
\text { faults }\end{array}$} & $>50 \mathrm{~m}$ & 8073 & 4.36 & 9 & 5.77 & 1.32 \\
\hline & $50 \mathrm{~m}-100 \mathrm{~m}$ & 7506 & 4.06 & 9 & 5.77 & 1.42 \\
\hline & $100 m-150 m$ & 6896 & 3.73 & 6 & 3.85 & 1.03 \\
\hline & $150 \mathrm{~m}-200 \mathrm{~m}$ & 6076 & 3.28 & 5 & 3.21 & 0.98 \\
\hline & $200 \mathrm{~m}-250 \mathrm{~m}$ & 5597 & 3.02 & 9 & 5.77 & 1.91 \\
\hline & $250 \mathrm{~m}-300 \mathrm{~m}$ & 5223 & 2.82 & 8 & 5.13 & 1.82 \\
\hline & $300 \mathrm{~m}-350 \mathrm{~m}$ & 4788 & 2.59 & 5 & 3.21 & 1.24 \\
\hline & $>350 \mathrm{~m}$ & 140909 & 76.14 & 105 & 67.31 & 0.88 \\
\hline \multirow{8}{*}{$\begin{array}{l}\text { Distance from } \\
\text { rivers }\end{array}$} & $>50 \mathrm{~m}$ & 73672 & 39.81 & 70 & 44.87 & 1.13 \\
\hline & $50 \mathrm{~m}-100 \mathrm{~m}$ & 53136 & 28.71 & 49 & 31.41 & 1.09 \\
\hline & $100 m-150 m$ & 29594 & 15.99 & 26 & 16.67 & 1.04 \\
\hline & $150 m-200 m$ & 15233 & 8.23 & 9 & 5.77 & 0.70 \\
\hline & $200 \mathrm{~m}-250 \mathrm{~m}$ & 7540 & 4.07 & 1 & 0.64 & 0.16 \\
\hline & $250 \mathrm{~m}-300 \mathrm{~m}$ & 3097 & 1.67 & 0 & 0.00 & 0.00 \\
\hline & $300 m-350 m$ & 1431 & 0.77 & 0 & 0.00 & 0.00 \\
\hline & $>350 \mathrm{~m}$ & 1365 & 0.74 & 1 & 0.64 & 0.87 \\
\hline \multirow{8}{*}{$\begin{array}{l}\text { Distance from } \\
\text { major roads }\end{array}$} & $>50 \mathrm{~m}$ & 7251 & 3.92 & 31 & 19.87 & 5.07 \\
\hline & $50 \mathrm{~m}-100 \mathrm{~m}$ & 6604 & 3.57 & 12 & 7.69 & 2.16 \\
\hline & $100 \mathrm{~m}-150 \mathrm{~m}$ & 6412 & 3.46 & 11 & 7.05 & 2.04 \\
\hline & $150 \mathrm{~m}-200 \mathrm{~m}$ & 6312 & 3.41 & 9 & 5.77 & 1.69 \\
\hline & $200 \mathrm{~m}-250 \mathrm{~m}$ & 6232 & 3.37 & 13 & 8.33 & 2.47 \\
\hline & $250 \mathrm{~m}-300 \mathrm{~m}$ & 6156 & 3.33 & 5 & 3.21 & 0.96 \\
\hline & $300 m-350 m$ & 5942 & 3.21 & 6 & 3.85 & 1.20 \\
\hline & $>350 \mathrm{~m}$ & 140159 & 75.73 & 69 & 44.23 & 0.58 \\
\hline \multirow{9}{*}{ Land use } & Cliff & 94 & 0.05 & 0 & 0.00 & 0.00 \\
\hline & Cultivation & 61497 & 33.23 & 13 & 8.33 & 0.25 \\
\hline & Forest & 98271 & 53.10 & 90 & 57.69 & 1.09 \\
\hline & Orchard & 55 & 0.03 & 0 & 0.00 & 0.00 \\
\hline & Grass & 5817 & 3.14 & 13 & 8.33 & 2.65 \\
\hline & Bush & 12448 & 6.73 & 40 & 25.64 & 3.81 \\
\hline & Sand cover & 6880 & 3.72 & 0 & 0.00 & 0.00 \\
\hline & River & 1 & 0.00 & 0 & 0.00 & 0.00 \\
\hline & Pond/lake & 5 & 0.00 & 0 & 0.00 & 0.00 \\
\hline
\end{tabular}

The FR of all the thematic layers used in the present study is calculated in Microsoft Excel and is given in Table 1. Using these FR values, the thematic maps were reclassified by the help of the spatial analyst tool in ArcGIS 10. These reclassified layers were then added using the raster calculator to get the final susceptibility map (Fig. 5).

\section{RESULTS AND DISCUSSION}

From the desk study as well as from detailed field survey, 187 different types of landslides were identified and mapped (Fig. 1). Among the 187 different types of landslides 150 (80\%) landslides training data were used to prepare model. Frequency ratio model has been used for making the susceptibility map. The dominant type of failure is translational type, with some rotational, falls, debris flow and topples. River damming as well as damage to whole settlement can be seen in some areas (Fig. 3).

The landslide density increases on increasing slope angle and reach at maximum in the slope class $35^{\circ}-40^{\circ}$ (Table-1). Deoja et al. (1991) showed increasing relationship of landslide density with slope angle up to $35^{\circ}$ and is highest in $25^{\circ}-35^{\circ}$ slope class. The landslide density is higher in bushes and grassland at 1200-1500 m elevation (Table 1). Grass and bushes present at $1200-1500 \mathrm{~m}$ elevation terrain generally have $30^{\circ}-45^{\circ}$ slope angle (Table 1). Grass and bushes influence parameters, like cohesion, internal frictional angle and pore water pressure. Hence, combination of these factors as slope angle, elevation and land cover classes makes the area more susceptible to landslides.

Presence of the Kapurkot Thrust in the Dangri Formation which is dominated by soft rocks such as phyllite and slate make the formation most susceptible to landslide (Fig. 2). The Dangri Formation is followed by Dhorbang Khola, Salyan Diamictite and Ranagaun formations. The Dhorbang Khola Formation near Khamari and Ramri village is pinched by thrust faults and $30^{\circ}-55^{\circ}$ dip slope rage makes this formation susceptible for landsliding. Syncline fold near Kapurkot comprise Phalabang Formation at its core making this formation more stable. Salyan Diamictite and Balle Quartzite lie toward outer limb. Weak lithology such as diamictite with clasts of limestone, dolomite and quartzite makes Salyan Diamictite more prone to failure than Balle Quartzite. The Ranagaun Formation is susceptible to landsliding as the MBT passes through this formation and weak lithotype such as siltstone and clay stone are dominant here.

Undercutting process of river and improper road construction practices exposes the joints and fractures that makes natural slope unstable. Both the river and road buffer zone shows landslide density to be higher within the close distance from the drainage and highway. 
The final landslide susceptibility map is classified into 5 different classes, as very low, low, medium, high, and very high hazard zones (Fig. 5). According to the LSM, $11.5 \%$ of the total area falls in the very high susceptibility zone. Similarly, $18 \%$ falls in high, $21 \%$ in moderate, $22.5 \%$ in low and remaining $27 \%$ falls in very low susceptibility zone respectively.

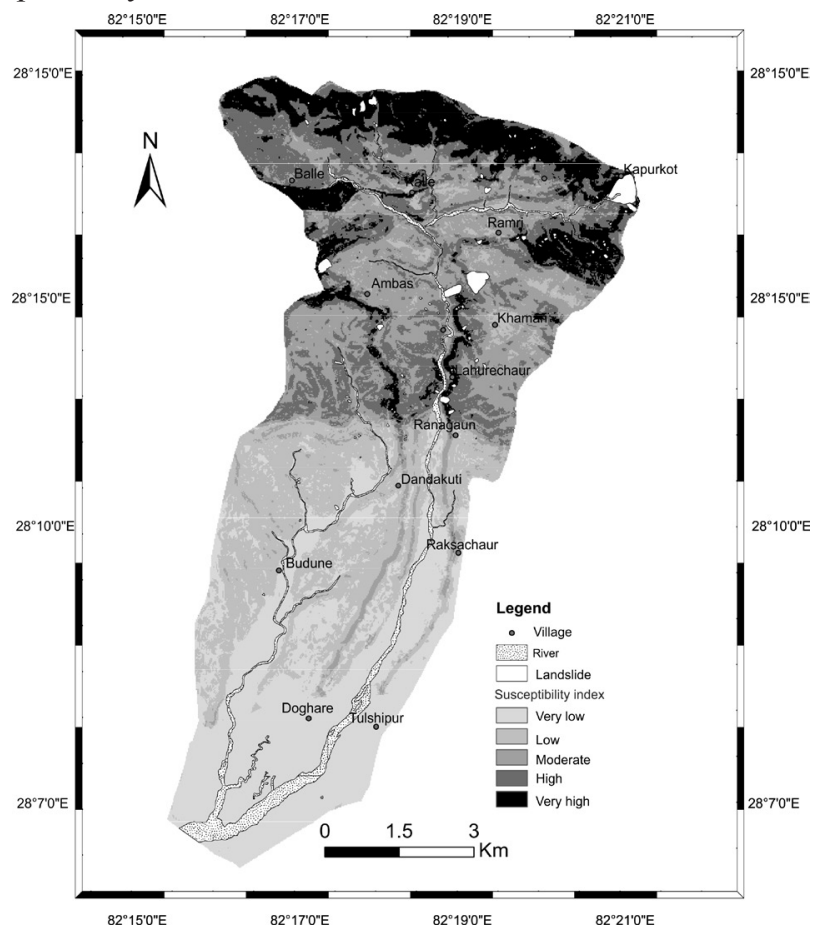

Fig. 5: Final landslide susceptibility map based on frequency ration (FR) model.

The validation of the susceptibility map was performed by using both the training data $(80 \%)$ of landslides and validation data $(20 \%)$ of landslides. The area under curve shows the success rate of the model to be $85.1 \%$ and the Predication accuracy to the $78.76 \%$ (Fig. 6 )

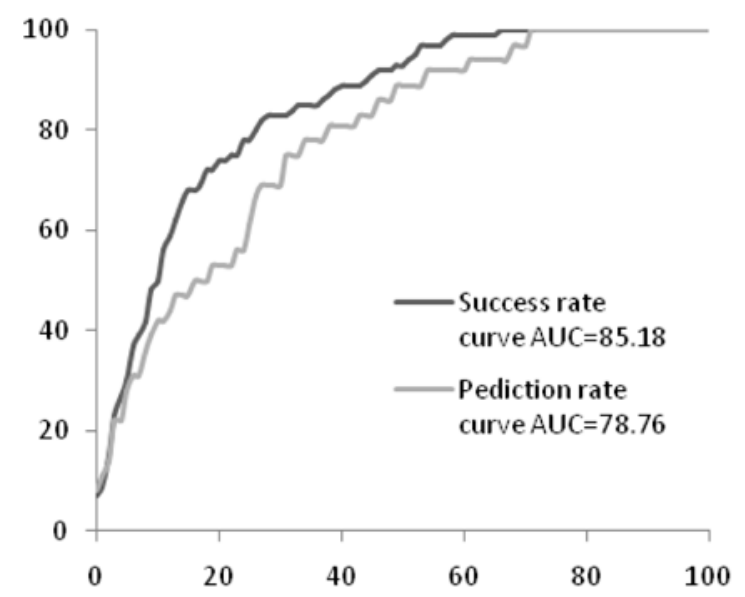

Fig. 6: Area under the curve (AUC) for the landslide susceptibility maps produced by FR model (Success rate curve and prediction rate curve).

\section{CONCLUSIONS}

To prepare the landslide susceptibility map of TulsipurKapurkot road section and its surrounding region using frequency ratio model, nine landslide-conditioning factors (i.e., slope, aspect, elevation, curvature, distance from road, distance form fault, distance from drainage, land use and lithology) were considered. A landslide inventory map was prepared using Google earth image evaluation and detailed field survey using GPS. In this process, a total of 187 different types of landslides were identified and mapped. From these 187 mapped landslides, $150(80 \%)$ were randomly selected for generating a model and the remaining $37(20 \%)$ were used for validation proposes. Finally, landslide susceptibility map of the region was obtained and it was validated using area under curve (AUC). From the analysis, the success rate of the model is found to be $85.18 \%$ and predictive accuracy is $78.76 \%$. The resultant susceptibility map shows that most part of the Tulsipur-Kapurkot road section is under high susceptibility zone. The improper practices for road cut as well as improper drainage management along the highway have initiated many landslides along the highway. This type of map is very useful for the general land use planning as well as for implementing further development works in the region.

\section{ACKNOWLEDGEMENT}

We sincerely thank the Central Department of Geology, Tribhuvan University, Kirtipur and National Academy of Science and Technology, Lalitpur for all the facilities provided during the research work. We would also like to acknowledge the people living in the study area for their help and support.

\section{REFERENCES}

Bonham-Carter, G. F., 1994, Geographic information systems for geoscientists: modeling with GIS. In: Bonham-Carter $\mathrm{F}$ (ed.) Computer methods in the geosciences. Pergamon, Oxford, $398 \mathrm{p}$.

Brabb, E., Colgan, J. P., and Best, T., 1998, Map showing inventory and regional susceptibility for Holocene debris flows and related fast-moving landslides in the conterminous United States, U.S Department of the Interior. USGS, pp. 1-5.

Carrara, A., Guzzetti, F., Cardinali, M., and Reichenbach, P., 1999, Use of GIS Technology in the Prediction and Monitoring of Landslide Hazard. Nat. Hazard, v. 20(2), pp. 117-135.

Cascini, L., 2008, Applicability of landslide susceptibility and hazard zoning at different scales, Engg. Geol., v. 102, pp. 164-177.

Chen, Z. and Wang, J., 2007, Landslide hazard mapping using logistic regression model in Mackenzie Valley, Canada. Nat. Hazard, v. 42(1), pp.75-89. 
Cooke, R. and Doornkamp, J., 1990, Geomorphology in Environmental Management: a new introduction. Oxford Univ. Press, Oxford.

Dahal, R. K., Hasegawa, S., Yamanaka, M., and Nishino, K., 2006, Rainfall triggered flow-like landslides: understanding from southern hills of Kathmandu, Nepal and northern Shikoku, Japan. Proc 10th Int. Cong. IAEG, The Geological Society of London, IAEG2006 Paper No. 819, pp.1-14.

Dai, F. C. and Lee, C. F., 2002, Landslide characteristics and slope instability modeling using GIS, Lantau Island, Hong Kong. Geomorphology, v. 42, pp. 213-228.

Deoja B., Dhital M. R., Thapa, B., and Wagner, A., 1991, Mountain risk engineering handbook, ICIMOD, Kathmandu, 857 p.

Dhital, M. R. and Kizaki, K., 1987a, Structural aspect of the Northern Dang Lesser Himalaya, Bull Ryukyu Univ., Okinawa, Japan, v. 45, pp. 159-182.

Dhital, M. R. and Kizaki, K., 1987b, Lithology and stratigraphy of the Northern Dang Lesser Himalaya, Bull Ryukyu Univ., Okinawa, Japan, v. 45, pp. 183-244.

Dhital, M. R., Gajurel, A. P., Pathak, D., Paudel, L. P., and Kizaki, K., 1995, Geol. and structure of the Siwaliks and Lesser Himalaya in Surai khola-Bardanda area, midwestern Nepal. Bull. Dept. Geology, Tribhuvan Univ., Kathmandu, v. 4 (Sp. Issue), pp. 1-70.

Dhital, M. R., 2015, Lesser Himalaya of Karnali Bheri Region; Geology of Nepal Himalaya, pp. 1039-1040, Springer.

Donati, L. and Turrini, M. C., 2002, An objective method to rank the importance of the factors predisposing to landslides with the GIS methodology: application to an area of the Apennines (Valnerina; Perugia, Italy). Engg. Geol., v. 63, pp. 277-289.

Gomez, H. and Kavzoglub, T., 2005 Assessment of shallow landslide susceptibility using artificial neural networks in Jabonosa River Basin, Venezuela. Engg. Geol., v. 78, pp. 11-27.

Guzzetti, F., Carrara, A., Cardinalli, M., and Reichenbach, P., 1999, Landslide hazard evaluation: a review of current techniques and their application in a multi-case study, central Italy. Geomorphology, v. 31, pp. 181-216.

Laudari, D., 2001, Geomorphological study and drainage basin analysis in the eastern part of Dang valley, mid western Nepal, A Thesis submitted to CDG, Tribhuvan University (Unpublished).

Lee, S. and Min, K., 2001, Statistical analysis of landslide susceptibility at Yongin, Korea. Environ. Geol., v. 40, pp. 1095-1113.

McDermid, G. and Franklin, S., 1995, Remote sensing and geomorphometric discrimination of slope processes,
Zeitschrift fur Geomorphologie, v. 101, pp. 165-185.

Nandi, A. and Shakoor, A., 2009, A GIS-based landslide susceptibility evaluation using bivariate and multivariate statistical analyses, Engg. Geol., v. 110, pp. 11-20.

Nayava, J. L., 1980, Rainfall in Nepal. The Himalayan Review, Nepal Geograph. Soc., v. 12, pp. 1-18.

Pradhan, B. and Lee, S., 2009, Landslide risk analysis using artificial neural network model focusing on different training sites. Int. Jour. Physical Sci, v. 3(11), pp. 1-15.

Pradhan, B., 2010. Landslide susceptibility mapping of a catchment area using frequency ratio, fuzzy logic and multivariate logistic regression approaches. Jour. Ind. Soc. Remote Sensing, v. 38(2), pp. 301-320.

Regmi, A. D., Devkota, K. C., Yoshida, K., Pradhan, B., Pourghasemi, H. R., Kumamoto, T., and Akgun, A. 2013, Application of frequency ratio, statistical index, and weights-of-evidence models and their comparison in landslide susceptibility mapping in central Nepal Himalaya. Arab. Jour. Geosci, v. 7(2), pp. 725-742.

Regmi, A. D., Yoshida, K., Pourghasemi, H. R., Dhital, M. R., and Pradhan, B., 2014, Landslide susceptibility mapping along Bhalubang-Shiwapur area of mid-western Nepal using frequency ratio and conditional probability models. Jour. Mountain Sci, v. 11(5), pp. 1266-1285.

Searle, M. P., Windley B, Coward, M., Cooper, D., Rex, A., Rex, D., Tingdong, L., Xuchang, X., Jan, M., Thakur, V., and Kumar, S., 1987, The closing of Tethys and the tectonics of the Himalaya. Geol. Soc. Am. Bull, v. 98, pp. 678-701.

Soeters, R. and van Westen, C. J., 1996, Slope instability recognition, analysis and zonation In: Turner, A.K and Schuster, R. L. (Eds.), Landslides: Investigation and Mitigation, Special Report 247. Transportation Research Board National Research Council, Washington D.C, pp. 129-177.

van Westen, C. J., Castellanos, E., and Kuriakose, S. L., 2008, Spatial data for landslide susceptibility, hazard, and vulnerability assessment: an overview. Engg. Geol, v. 102, pp. 112-131.

Varnes, D. J., 1984, Landslide hazard zonation, a review of principles and practice, International Association of Engineering Geology Commission on Landslides and Other Mass Movements on Slopes, UNESCO, Paris, $63 \mathrm{p}$.

Vivas, L., 1992, Los Andes Venezolanos, Academia Nacional de la Historia, Caracas. 300 p.

Wieczorek, G. F., 1984, Preparing a detailed landslideinventory map for hazard evaluation and reduction. Bull. Assoc. Engg. Geol., v. 21(3), pp. 337-342. 